\title{
The Covid-19 Pandemic and its Impact on Gamification within ESL Virtual Classrooms: A Literature Review
}

Sharifah Kuraisya Syed Ibrahim, Siti Munirah Kamaruddin, Melor Md. Yunus \& Harwati Hashim

To Link this Article: http://dx.doi.org/10.6007/IJARBSS/v11-i12/11764

DOI:10.6007/IJARBSS/v11-i12/11764

Received: 21 October 2021, Revised: 24 November 2021, Accepted: 10 December 2021

Published Online: 26 December 2021

In-Text Citation: (Ibrahim et al., 2021)

To Cite this Article: Ibrahim, S. K. S., Kamaruddin, S. M., Yunus, M. M., \& Hashim, H. (2021). The Covid-19 Pandemic and its Impact on Gamification within ESL Virtual Classrooms: A Literature Review. International Journal of Academic Research in Business and Social Sciences, 11(12), 268-277.

Copyright: (c) 2021 The Author(s)

Published by Human Resource Management Academic Research Society (www.hrmars.com)

This article is published under the Creative Commons Attribution (CC BY 4.0) license. Anyone may reproduce, distribute, translate and create derivative works of this article (for both commercial and non0-commercial purposes), subject to full attribution to the original publication and authors. The full terms of this license may be seen

at: http://creativecommons.org/licences/by/4.0/legalcode

Vol. 11, No. 12, 2021, Pg. $268-277$

http://hrmars.com/index.php/pages/detail/IJARBSS

JOURNAL HOMEPAGE

Full Terms \& Conditions of access and use can be found at http://hrmars.com/index.php/pages/detail/publication-ethics 


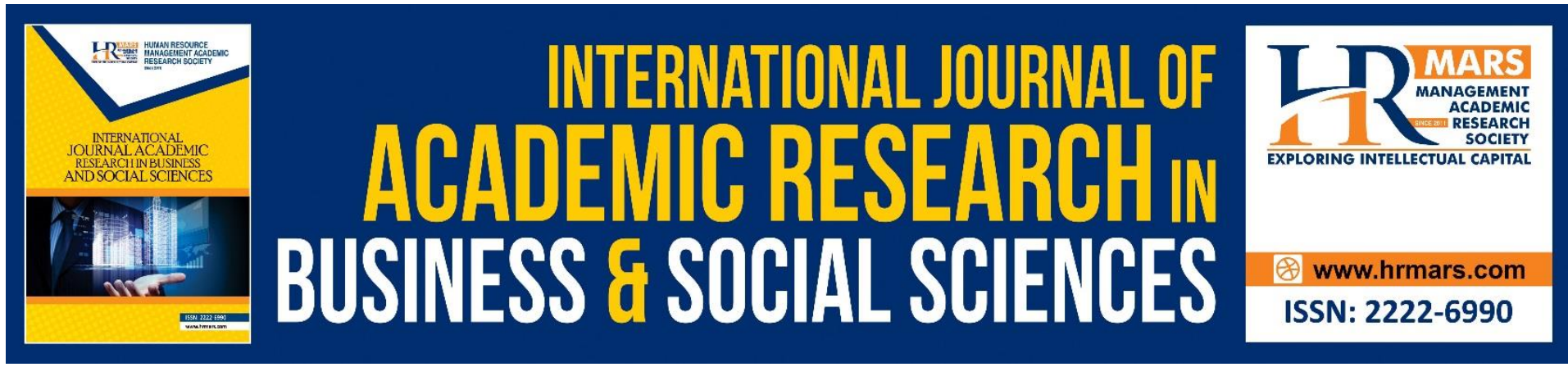

\title{
The Covid-19 Pandemic and its Impact on Gamification within ESL Virtual Classrooms: A Literature Review
}

\author{
Sharifah Kuraisya Syed Ibrahim, Siti Munirah Kamaruddin, \\ Melor Md. Yunus \& Harwati Hashim \\ Faculty of Education, Universiti Kebangsaan Malaysia \\ Email: melor@ukm.edu.my
}

\begin{abstract}
The Covid-19 pandemic is a health crisis that has been affecting the world since December 2019. The death toll that keeps spiking up day by day has led the government to take precautions in schools in order to ensure students' health and safety. The temporary closure of various educational institutions including universities, schools and kindergartens has given a significant impact on our education system. This unprecedented situation has resulted in the transition of the face-to-face teaching method to virtual learning. This literature review focuses on the use of gamification as a tool for language learning and teaching, specifically for the educators and learners of English as a Second Language (ESL) in conducting virtual lessons in the middle of the Covid-19 pandemic. Thus, the impacts and challenges of the utilisation of gamification tools in the virtual classrooms conducted due to Covid-19 pandemic have been identified as a way to enhance ESL virtual classrooms through improvements in the method of teaching for students' educational development with regard to ESL knowledge.
\end{abstract}

Keywords: Covid-19, Impact, Gamification, English as a Second Language (ESL), Virtual Classroom

\section{Introduction}

The Coronavirus pandemic which is also known as Covid-19 has been affecting countries worldwide since December 2019. The outbreak of this pandemic has transcended globally just within months and has given a huge impact on the nations. As of October 2020, almost 51.8 million confirmed cases have been reported, which have led to almost 1.2 million deaths across the world (World Health Organization, 2020). The outbreak has not only affected the world's economy but has also given a severe impact on the education system worldwide including in Malaysia. Due to the rising number of cases and deaths, the Malaysian government has taken vast action by implementing the movement control order (MCO) which has also forced the closure of all the educational institutions temporarily. It is indeed a challenging phase for both educators and students. UNESCO (2020) stated that 21.7 million students and 1.3 million teachers have been affected by the temporary closure of the 
educational institutions. Approximately a billion students worldwide, with nearly 120 countries involved, have stopped face-to-face learning due to the Covid-19 pandemic (Shahzad et al., 2020). As a consequence, the traditional 'face-to-face' method of teaching has been shifted into the modern method of teaching which is done with the usage of technology. Conducting virtual classrooms has been made possible with the advancement of technology, and educators as well as students need to rely on this new pedagogical concept of teaching and different modes of delivery. Conducting a class virtually is the most significant teaching method that is used by educators during this critical situation. Applications such as Padlet, GrammarFlip, DuoLingo, Kahoot!, Google Classroom, Edpuzzle and Quizizz are examples of educational tools that have been used to interact with and encourage students' participation in the virtual classroom. This is due to the fact that the ways of teaching need to be enhanced to ensure students' engagement through an interactive learning session.

In a study conducted by Umar \& Hassan (2015) on the integration of ICT among Malaysian teachers and its perceived impact on students, many teachers revealed that they did not integrate the use of ICT in their classroom particularly due to their concern of not being able to complete the syllabus despite admitting to the positive impacts brought by ICT in their classroom. With the spread of Covid-19, these teachers are forced to integrate the use of ICT in their classroom and gamification is part of ICT. According to Scepanovic et al. (2015), gamification can be defined as the utilization of game mechanics to transform the learning experience into a game with the basic principle to reach a certain goal such as to win a prize, beat the competitor, be ranked first in the leaderboard and even accomplish the assignment or task given. It eventually will create motivation, engagement as well as certain behavioural patterns and emotion among the students. In a systematic review on the use of gamification in English as a Second Language (ESL) classrooms done by Dehghanzadeh et al (2019), it is believed that the integration of gamification in ESL classrooms is still fairly new as the articles found with regard to the topic were published between 2014 and 2019. Hence, with the presence of gamification, learning sessions would be made more fun and could help accommodate the students' needs especially for those who are visual learners. As affirmed by Villagrasa et al (2014), gamification will be one of the methods to improve student performance in their learning process. It is believed with the various principles of gamification such as the rewards, badges and leaderboards, students will gain focus and it will motivate them to participate in their virtual classroom. In fact, the feeling of accomplishment will also push them to strive in order to go to the next level. With that being said, this paper provides the literature review on the impact brought by the Covid-19 pandemic on the use of gamification within ESL virtual classrooms, with regard to its positive impacts on students' language learning process and the challenges faced by educators and learners. In line with this, this literature review study will attempt to provide answers to the following research questions:

1. What are the positive impacts brought by the use of gamification within ESL virtual classrooms due to the spread of Covid-19?

2. What are the challenges faced by educators and learners with the integration of gamification in ESL virtual classrooms due to Covid-19?

\section{Literature Review}

\section{Gamification and its Tools for Language Teaching and Learning}

Owing to the essential fragment technology plays in language education, many educators have now begun to incorporate the use of digital games in their classroom (Idris et 
al., 2020). "Gamification is the use of game design elements in non-game contexts" (Deterding et al., 2011, p. 9). Gamification within the ESL virtual classroom corresponds greatly to this definition. This is due to the fact that the goals and aims of the lesson are not exclusively directed at creating entertainment for the students, instead it will be part of the learning process (Flores, 2015). Thus, it is clear that "Gamification" within ESL virtual classrooms serves as a way of making learning, and education itself, a fun process in which students get to immerse themselves.

Myriads of gamification tools have gained popularity and recognition all over the world in recent years. However, in order for teachers to integrate the use of these applications in their virtual classrooms, it is vital that they are digitally literate. On the other hand, students are also required to be somewhat competent digitally. According to Hatlevik and Christophersen (2013), digital competence among students can be defined in three different aspects namely the technological skills to retrieve information, assess collected data and finally use digital tools or media to produce and communicate information. In this review, the third aspect of the definition provided, is the most relevant.

Among countless educational gamification tools available, one of the most renowned applications is probably Kahoot!. Kahoot!, originally introduced in 2013, is a digital platform mainly created for quizzes, discussions and surveys in the form of games (Kaur \& Naderajan, 2019). Graham (2015) who came up with an intensive paper on exploring the use of Kahoot! acknowledged that the most typical type of Kahoot! exercise is the quiz in which students are required to gain points by responding to questions within a certain amount of time. These accumulated points will then be utilised to pick a few top winners. In terms of language teaching, Kahoot! could be used for vocabulary and grammar formative assessment. Teachers can opt to either use the existing materials available or come up with their own materials based on the topics of interest.

Bury (2017) stated that Quizizz, other than its ability to be a substitute for Kahoot!, is also a prominent digital tool which serves as a platform for students to assess their understanding and improvement in learning. A study conducted by Basuki and Hidayati (2019) on 250 students of English Language revealed students' preference for Quizizz over Kahoot! citing its independent nature in providing students opportunities to learn as the main reason alongside the excitement, motivation and fun it brings. Just like Kahoot!, Quizizz is another gamification tool which allows English language teachers to teach English vocabulary and grammar virtually, in an exhilarating way.

Quizizz and Kahoot! are only two among a plethora of gamification tools available to be utilised for virtual language teaching. Other applications may include Gimkit, Quizlet and Socrative. Gamification gives learners the chance to be completely involved in the process of learning due to its experiential and 'play' nature as it attracts learners' whole attention and ensures knowledge retention (Tan et al., 2018). The existence of gamification and its tools has made language learning in virtual classrooms a fun process, during which students can enhance their knowledge and simultaneously enjoy themselves.

\section{Covid-19 and Its Positive Impact on Gamification in a Virtual ESL Classroom}

The unfortunate spread of the Covid-19 pandemic has led to virtual education as the only means of teaching and learning. Virtual teaching and learning process differs greatly from the traditional teaching and learning process in the sense that teaching is done from a distance by teachers, hence resulting in teachers not being able to fully monitor their students. It is essential for teachers to look for a way to ensure continuous engagement by 
the students in a virtual classroom. According to Flores (2015) the process of teaching and learning the second language is automatically enhanced with the game elements used in Gamification. Therefore, it is obvious that Gamification is one way for teachers to guarantee the success of their lessons in the current situation. This, in chorus, makes gamification, which is a fairly new part of education, become something that is more common. Hence, it is undeniable that gamification and even more specifically the gamification tools, have now become a crucial part of language teaching due to the need to make virtual classrooms a fun educational platform.

As gamification becomes a significant part of the English Language virtual classroom, more English teachers are now aware of the fact that Gamification makes language learning fun as it increases students' level of enjoyment. Teachers' preference over traditional methods (Umar \& Hassan, 2015) has slowly been changed due to the rapid spread of Covid19. As stated by Kaur and Naderajan (2019), Gamification provides students with motivation as its goals are to make the learning process more fascinating and endorse a joyful study environment for students. Students get to gain knowledge and simultaneously enjoy themselves in the ESL virtual classroom during this pandemic. The study by Basuki and Hidayati (2019) confirms this notion as the results of the research indicate that half of the participants, who were students, see gamification tools i.e Kahoot! and Quizizz as exciting, interesting, motivating and fun.

It goes without saying that learners' motivation and engagement are part of the key contributors in determining their success. Covid-19 has become a major reason for the need of virtual learning. Nevertheless, some students are very minimally engaged in the virtual classroom as they find the task to juggle life in lockdown as well as learning, a rather daunting one and achieving 'a sense of belonging' is yet another tough mission due to the insufficient amount of time spent with their friends (Hill \& Fitzgerald, 2020). The use of Gamification could be of a great help in a virtual classroom as students will be more attentive, engaged and motivated in their English class that is done virtually. This can be supported by a statement from Göksün and Gürsoy (2019) who stated that Gamification should be a novel method within the education system as it could be impactful towards learners' motivation and engagement. Studies that have proven the effectiveness of gamification towards students' motivation and engagement include Zarzycka-Piskorz (2016) through the winning and reward system; Wang and Lieberoth (2016) through points and audio; Tan et al (2018) based on its effects on learners' intrinsic and extrinsic motivation; Muhridza et al (2018) through competitive gestures indicating full engagement among learners.

On the other hand, a study conducted by Hashim et al (2019) in a Malaysian secondary school concluded that the use of game-based applications (i.e. Socrative, PowerPoint Challenge Game and Kahoot1) that tests students' language ability, particularly their grammar knowledge, is effective based on the post-test results which showed significant improvement among the students compared to the pre-test results. Similar finding was found with regard to vocabulary improvement in a study done in Pakistan by Perveen, et al (2016) on 150 students in public schools. Students successfully learned the meaning of words introduced to them through games albeit not digital ones and were even adept enough to incorporate the use of these words as they speak. There are also other studies with similar results (e.g., Karaaslan et al., 2018) in the study of collocation and parts of speech use among university students; Muhridza et al (2018) in the research on the use of synonyms among tertiary level students; Yunus \& Azman (2019) in the study of irregular verbs use through Kahoot! among primary school students). This proves that ESL educators who are at odds on how to assess 
their students' language learning progress due to the spread of Covid-19, are now able to assess students' general understanding of the English Vocabulary and Grammar while conducting their classes virtually.

\section{The Challenges Faced by English Educators and Learners with the Integration of Gamification in ESL Virtual Classrooms due to Covid-19}

Despite the efficiency and engagement brought by the use of gamification in virtual learning, it is undeniable that there are also challenges that are encountered by English educators and learners. The most impactful challenge is the smoothness of the gamification process itself due to internet connectivity. In Malaysia, the preparedness towards the shifting from traditional learning method to the modern learning method is still insufficient. It can be proven based on the research by Adams et al (2018) who studied the E-learning readiness among students of diverse backgrounds in a leading Malaysian higher education institution. The outcome of this research has revealed that students were still at a moderate level of readiness for E-learning and one of the reasons is the availability of technological resources. The new norms of teaching due to the Covid-19 pandemic has been seen as a challenge for educators as well for learners. It is undeniably true that Malaysia is still suffering from poor internet connection coverage especially for those who are staying in rural areas, particularly in Sabah and Sarawak. This statement can be proven with the recent news which reported that a student from a public university in Malaysia, had to stay overnight and climb up a tree to get a stable internet connection to sit for her examination (Jacobs \& Subramaniam, 2020). Similarly, the integration of gamification in learning especially in ESL virtual classrooms would require stable internet connectivity and this might be a challenge that needs to be faced by educators and learners. As highlighted by Idris et al (2020) the problem of the lack of information and technology infrastructure such as internet connectivity and computer laboratories, particularly in rural or even in urban areas, need to be addressed if we want to meet the demands of $21^{\text {st }}$ century learning. They also suggested that the government should play their part by providing a conducive, contemporary and apposite learning environment which is appropriate for our present generations. It shows that our technological advancement still needs to be improved in order to make sure that our education system is well-equipped to cater to the needs of the future generation.

Pazilah et al (2019) claimed that one challenge of conducting virtual classrooms is the distraction that learners might face when they are having a class virtually. It might happen if the learners surf the internet without their parents' supervision. With the current entertainment provided by various social networking sites that we have nowadays, such as Instagram, Tiktok, Twitter and Facebook, it is undeniable that learners might misuse their virtual class time and get distracted which will eventually give a negative impact on their learning progress. It can be supported with a study by McCoy (2020) on Gen Z and digital distractions in the classroom which had revealed that students were texting, replying to emails and surfing through social networking sites during the class. As a result, they were distracted and not focused in the class. These students will also eventually miss the instruction given by the teacher and this will leave a negative impact on their understanding and performance in the class.

The utilization of technology in a virtual classroom is vital especially in the middle of the Covid-19 pandemic. Educators and learners are required to use ICT as the main medium of learning and teaching. As mentioned by Zeehan et al (2020), educators must be prepared to face challenges in shifting to digital technology and the advancement of our future 
education due to the evolution of cyber physical which will leave a great impact on our education system. Nevertheless, it is undebatable that educators should also be provided with a proper training to enhance their skills, knowledge and build up their confidence. In addition, technological competence and experience are also necessary for educators to integrate technology in learning and teaching (Cheok et al., 2017). Hence, it is crucial for us to identify the challenges that learners and educators might face in order to ensure that the objective of the lesson in a virtual classroom specifically through gamification can be achieved.

The emergence of gamification as a learning tool could be a great challenge, not only for the learners but also for the educators in context of the design as well as the contents. In ESL virtual classrooms, the educators need to identify the level of the learners' competencies before they can integrate gamification in their learning process. According to Lee and Hammer (2011) gamification projects need to be designed specifically to equip the learners' learning environments. It is also important to make sure it can address the real challenges and problems faced by the learners and emphasise on the areas where gamification can provide the maximum values for them. In fact, the contents of the games also need to correspond to the nature of the needs and degree of difficulty that could be handled by the learners (Idris et al., 2020). Thus, the specific design of the gamification tool is important to ensure that learning progress specifically for ESL will be fun and interactive.

\section{Conclusion}

As stated earlier, this paper provides a literature review on the impact of Covid-19 on the use of gamification within ESL virtual classrooms in terms of its positive impacts on students' language learning process and the challenges faced by educators and learners with the integration of gamification in ESL virtual classrooms. This is due to the increase in the use of gamification tools by ESL teachers to make English language a fun subject for students to learn during this pandemic. As mentioned in the preceding sections, prior to Covid-19, many teachers were not willing to incorporate the use of gamification as catching up with the syllabus was more of their main concern, and the former would only slow down the progress of their lesson. Nevertheless, through this literature review, it has been discovered that the use of gamification within ESL virtual classrooms can exponentially increase students' level of enjoyment, increase students' motivation and engagement in the classroom and simultaneously aid teachers in the assessment of grammar and vocabulary comprehension.

Nevertheless, there are some challenges that both ESL learners and educators will have to face with the integration of gamification within the virtual classroom due to the spread of Covid-19. Among the challenges are the smoothness of the gamification process which could be affected by internet connectivity, the distraction that students might face while having class virtually, certain level of technological competency that needs to be acquired by both educators and learners as well as the design and the content of the gamification tools which could confuse both learners and educators. Some implications could be acquired from this study which could be beneficial to ESL learners and educators especially in the middle of this chaotic situation due to the incessant spread of the Covid-19 pandemic. The challenges faced by ESL educators and learners with the integration of gamification in their effort of making virtual learning a favourable and useful process, need to be addressed and looked into by the authority in order to ease the process of ESL teaching and learning which is done virtually during this pandemic. Finally, the findings gathered in this review which come from various past research could help all stakeholders involved to see the real 
luxury gamification provides in a virtual classroom and simultaneously acknowledge the challenges which ought to be resolved so as to provide better ESL learning quality for the future generation especially in this era of rampant advent of gamification tools.

\section{Acknowledgement}

The authors would like to acknowledge Universiti Kebangsaan Malaysia under research grant No. GG-2020-024 and GG-2020-014.

\section{References}

Adams, D., Sumintono, B., Mohamed, A., \& Noor, N. S. M. (2018). E-Learning Readiness among Students of Diverse Backgrounds in a Leading Malaysian Higher Education Institution. Malaysian Journal of Learning and Instruction, 15(2), 227-256.

Basuki, Y., \& Hidayati, Y. (2019, April). Kahoot! or Quizizz: the Students' Perspectives. In Proceedings of the 3rd English Language and Literature International Conference (ELLiC)(2019).

Bury, B. (2017, October). Testing Goes Mobile-Web 2.0 Formative Assessment Tools [Paper Presentation]. International Conference ICT for Language Learning.

Cheok, M. L., Wong, S. L., Ayub, A. F., \& Mahmud, R. (2017). Teachers' Perceptions of ELearning in Malaysian Secondary Schools. Malaysian Online Journal of Educational Technology, 5(2), 20-33.

Dehghanzadeh, H., Fardanesh, H., Hatami, J., Talaee, E., \& Noroozi, O. (2019). Using Gamification to Support Learning English as a Second Language: A Systematic Review. Computer Assisted Language Learning, 1-24. https://doi.org/10.1080/09588221.2019.1648298

Deterding, S., Dixon, D., Khaled, R., \& Nacke, L. (2011, September). From Game Design Elements to Gamefulness: Defining" Gamification". In Proceedings of the 15th international academic MindTrek Conference: Envisioning Future Media Environments (pp. 9-15). DOI: 10.1145/2181037.2181040

Flores, J. F. F. (2015). Using Gamification to Enhance Second Language Learning. Digital Education Review, 27, 32-54. https://doi.org/10.1344/der.2015.27.32-54

Göksün, D. O., \& Gürsoy, G. (2019). Comparing Success and Engagement in Gamified Learning Experiences via Kahoot and Quizizz. Computers \& Education, 135, 15-29. https://doi.org/10.1016/j.compedu.2019.02.015

Graham, K. (2015). TechMatters: Getting into Kahoot!(s): Exploring a Game-Based Learning System to Enhance Student Learning. LOEX Quarterly, 42(3), 6-7.

Hashim, H., Rafiq, R. M., \& Yunus, M. (2019). Improving ESL Learners' Grammar with GamifiedLearning. Arab World English Journal (AWEJ) Special Issue on CALL, (5), 41-50. https://dx.doi.org/10.24093/awej/call5.4

Hatlevik, O. E., \& Christophersen, K. A. (2013). Digital Competence at the Beginning of Upper Secondary School: Identifying Factors Explaining Digital Inclusion. Computers \& Education, 63, 240-247. https://doi.org/10.1016/j.compedu.2012.11.015

Hill, K., \& Fitzgerald, R. (2020). Student Perspectives of The Impact of COVID-19 on Learning. All Ireland Journal of Higher Education, 12(2), 1-9.

Idris, M. I., Said, N. E. M., \& Tan, K. H. (2020). Game-Based Learning Platform and its Effects on Present Tense Mastery: Evidence from an ESL Classroom. International Journal of Learning, Teaching and Educational Research, 19(5), 13-26. https://doi.org/10.26803/ijlter.19.5.2 
Irfan, N. U., \& Amat, S. A. H. (2015, February). Malaysian Teachers' Levels of ICT Integration and its Perceived Impact on Teaching and Learning. In 7th World Conference on Educational Sciences,(WCES-2015) (pp. 05-07). https://doi.org/10.1016/j.sbspro.2015.07.586

Jacobs, J., \& Subramaniam, P. (2020, October 19). Cover Story: The digital divide and disconnection. The Edge Malaysia. Retrieved from https://www.theedgemarkets.com/article/cover-story-digital-divide-anddisconnection

Karaaslan, H., Kilic, N., Guven-Yalcin, G., \& Gullu, A. (2018). Students' Reflections on Vocabulary Learning through Synchronous and Asynchronous Games and Activities. Turkish Online Journal of Distance Education, 19(3), 53-70. https://doi.org/10.17718/tojde.444640

Kaur, P., \& Naderajan, R. (2019). Kahoot! in the English Language Classroom. South East Asia Journal of Contemporary Business, Economics and Law, 20(6), 49-54.

Lee, J. J., \& Hammer, J. (2011). Gamification in Education: What, How, Why Bother?. Academic Exchange Quarterly, 15(2), 146.

McCoy, B. (2020). Gen Z and Digital Distractions in the Classroom: Student Classroom Use of Digital Devices for Non-Class Related Purposes. Journal of Media Education, 11(2), 523. https://en.calameo.com/read/0000917898a07ac2096e4

Muhridza, N. H. M., Rosli, N. A. M., Sirri, A., \& Samad, A. A. (2018). Using Game-Based Technology, KAHOOT! for Classroom Engagement. LSP International Journal, 5(2), 3748. https://doi.org/10.11113/Ispi.v5n2.77

Pazilah, F. N. P., Hashim, H., \& Yunus, M. M. (2019). Using Technology in ESL Classroom: Highlights and Challenges. Creative Education, 10(12), 3205-3212. DOI: 10.4236/ce.2019.1012244

Perveen, A., Asif, M., Mehmood, S., Khan, M. K., \& Iqbal, Z. (2016). Effectiveness of Language Games in Second Language Vocabulary Acquisition. Science International, 28(1), 633637.

Scepanovic, S., Zaric, N. A. D. A., \& Matijevic, T. (2015). Gamification in Higher Education Learning-State of The Art, Challenges and Opportunities. In The Sixth International Conference on e-Learning (eLearning-2015), 24-25 September 2015, Belgrade, Serbia

Shahzad, A., Hassan, R., Aremu, A. Y., Hussain, A., \& Lodhi, R. N. (2020). Effects of COVID-19 in E-Learning on Higher Education Institution Students: The Group Comparison between Male and Female. Quality \& Quantity, 1-22. https://doi.org/10.1007/s11135-02001028-z

Tan, A. L. D., Ganapathy, M., \& Kaur, M. (2018). Kahoot! It: Gamification in Higher Education. Pertanika Journal of Social Sciences \& Humanities, 26(1), 565-582.

Umar, I. N., \& Hassan, A. S. A. (2015). Malaysian Teachers' Levels of ICT Integration and its Perceived Impact on Teaching and Learning. Procedia - Social and Behavioral Sciences, 197, 2015-2021. http://dx.doi.org/10.1016/j.sbspro.2015.07.586

UNESCO. (2020). Covid-19 Impact on Education. Retrieved from https://en.unesco.org/covid19/educationresponse

Villagrasa, S., Fonseca, D., Redondo, E., \& Duran, J. (2014). Teaching Case of Gamification and Visual Technologies for Education. Journal of Cases on Information Technology (JCIT), 16(4), 38-57. DOI: 10.4018/jcit.2014100104

Wang, A. I., \& Lieberoth, A. (2016). The Effect of Points and Audio on Concentration, Engagement, Enjoyment, Learning, Motivation, and Classroom Dynamics Using Kahoot. 
In European Conference on Games Based Learning (Vol. 20). Academic Conferences International Limited.

World Health Organization. (n.d). WHO Coronavirus Disease (COVID-19) Dashboard. Retrieved from https://covid19.who.int/

Yunus, M. M., \& Azman, M. A. (2019). Memory Stay Or Stray?: Irregular Verbs Learning Using Kahoot!. Arab World English Journal (AWEJ) Special Issue on CALL, (5). https://dx.doi.org/10.24093/awej/call5.15

Zarzycka-Piskorz, E. (2016). Kahoot it or not? Can Games Be Motivating in Learning Grammar?. Teaching English with Technology, 16(3), 17-36.

Zeehan, F., Alias, R. A., \& Tasir, Z. (2020). Discovering Digital Technology Training Challenges for Future-Ready Educator: A Preliminary Study from Trainer Perspective. Universal Journal of Educational Research, 8(3A), 12-23. 